\title{
Fungal profile associated with spoilage of smoked catfish sold in Aba, Abia State, Nigeria
}

Ike Christian Chukwuemeka ${ }^{1,}{ }^{*}$, David Alex Chibuike ${ }^{1}$, Ogwuegbu Happiness Odinakachi 2 and Akwari Dike Kalu 1

${ }^{1}$ Department of Biological Sciences (Microbiology Programme), College of Basic and Applied Sciences, Rhema University, Nigeria, P.M.B. 7021 Aba, Abia State, Nigeria.

2 Department of Microbiology, Abia State University Uturu, P.M.B. 2000 Uturu, Abia State. Nigeria.

Publication history: Received on 23 February 2020; revised on 06 March 2020; accepted on 17 March 2020

Article DOI: https://doi.org/10.30574/gscbps.2020.10.3.0046

\begin{abstract}
Fungi associated with spoilage of smoked catfish (Clarias gariepinus) were evaluated using standard microbiological methods. A total of twenty five (25) samples were collected from Afule, Ariaria, Umugasi, Cemetery and Ahiaohuru markets in Aba metropolis and were analysed. Fungal loads ranged between $2.2 \times 10^{3} \pm 0.02 \mathrm{SFU} / \mathrm{g}$ and $4.5 \times 10^{4} \pm 0.14$ $\mathrm{SFU} / \mathrm{g}$. Four (4) fungal species were isolated to include two molds; (Aspergilus niger, Mucor species) and two yeasts; (Candida species, Rhodotorula species). The most prevalent isolates were Aspergilus niger (80 \%)and Mucor species $(73.33 \%)$, while the least prevalent was Rhodotorula species (6.67\%). Identified qualities of these fungi were their degradative ability which was observed during pathogenesis study as they render the catfish unfit for consumption with high virulence in causing major mycotic infections. Therefore, there is need for education and awareness campaign among handlers and sellers on proper hygiene practices to avert the imminent health hazards looming the economy from the shabby handling and processing techniques.
\end{abstract}

Keywords:Catfish; Fungi; Spoilage; Shelf life; Hygiene

\section{Introduction}

Fish and fisheries products are the most important nutritious food all over the world which represents about 15-20 \% of all animal protein on a global basis [1]. In Nigeria, fish has an edge over meat because it is cheaper and relatively more abundant and constitutes about $40 \%$ of the animal protein intake [1; 2]. Fish is a cheap source of animal protein with little or no religious rejection, which gives it an advantage over pork or beef. Fish is a rich source of lysine suitable for supplementing high carbohydrate diet. It is also a valuable source of vitamins A, B and E, iodine and oils containing polyunsaturated fatty acids [1;2]. In Nigeria, the short supplies of animal protein with the increasing human population have raised the cost of animal protein to a level almost beyond the reach of the low income group [3].

In Nigeria, fish can be eaten as fresh, preserved or processed. [4] reported that the percentage composition of the different processing and retailing methods of fish for consumption in the artisanal sector are as follows live fish $7 \%$, fresh fish $27 \%$, smoke dried $45 \%$, sun dried $11 \%$, and salted and sun dried $10 \%$. Smoke drying methods used in Nigeria requires low capital, investment and it is conducted in fishermen camps and fish processing centers in traditional smoking kilns of clay, cement blocks, drums or iron sheets [5]. This has resulted in a very short shelf life and low market value of the fishes as well as inability to withstand handling and transportation by retailers [6].

\footnotetext{
${ }^{*}$ Corresponding author: Ike Christian Chukwuemeka
} 
Therefore, there is need to preserve fishes after capture to prevent loss due to spoilage and to provide an excellent fresh flavour (just caught flavor). Technically, smoking is the process through which volatiles from thermal combustion of wood penetrate meat and fish flesh [7]. Smoking is the method of fish preservation effected by a combination of drying and deposition of naturally produced chemicals resulting from the thermal breakdown of wood [8]. Preserving food and other perishable products like fish and meat generally involves processes that impede growth of microorganisms either by the addition of growth inhibiting ingredients or adjusting storage conditions by freezing or drying [9]. Common salt is used to destroy the non-halophilic, spore forming bacteria and also osmophilic fungi. In spite of curing with salt, the qualities of dry fishes are being frequently contaminated with bacteria, fungi and insects [10]. Processing methods affect microorganisms in fishes, resulting in different types of micro-flora and different risks from spoilage organisms and pathogens [11].

In dried fish, the micro-flora is prevented from growing by the storage method used and the product may have long shelf life in the preserved state. However, the microbial load of fish rarely indicates the quality of the fish, but gives an indication of the risk of spoilage induced since each of the organisms has different ways of affecting the health conditions of consumers of such contaminated fish [12]. Therefore, this study was designed to enumerate the species of microorganisms associated with spoilage of smoked catfish (Clarias gariepinus) vended in Aba, Abia state.

\section{Material and methods}

\subsection{Sample collection}

A total of 25 samples of smoked catfish were bought at randomly from five different markets in Aba city. At each site, 5 samples of smoked catfish were bought from each seller. Replicate samples of smoked fish showing symptoms of spoilage were randomly selected from different market places in Aba, Abia State and such markets include: Afule market, Ariaria market, Umungasi market, Cemetery market and Ahiaohuru market. The smoked catfish samples were collected and kept separately in sterile ziploc bags and brought to the Microbiology Laboratory of Rhema University, Nigeria for analysis.

\subsection{Microbiological analysis of samples}

Ten fold serial dilutions of samples were done. Spread plate and streaking techniques [13] were used to enumerate and isolate fungi in the samples. One (1) gramme of each catfish sample was aseptically mashed, blended and homogenized in nine (9) milliliter of sterile distilled water to form $10^{-1}$ dilution. Serial dilutions of the homogenates were made to $10^{-}$ 2 and $10^{-3}$ and each dilution was plated in replicates using fortified sabouraud dextrose agar (SDA) for fungal enumeration and isolation. The purified fungal isolates were identified on the basis of macroscopic and microscopic characteristics by slide culture technique, and lactophenol staining. The schemes of [14] were used for the identification. The plates were incubated at $25 \pm 2{ }^{\circ} \mathrm{C}$ for 120 hours for mean fungal counts.

\subsection{Data analysis}

Data obtained from this research work were analysed using ANOVA. Descriptive statistics in form of means and standard deviation and Duncan post hoc were also used to assess the data. The analyses were done using SPSS 21.

\section{Results}

The mean fungal count (MFC) of smoked catfish samples sold in Aba market is shown in Table 1. The highest mean fungal count was recorded in sample 3 from Cemetery market ( $4.5 \times 10^{4} \pm 0.14 \mathrm{SFU} / \mathrm{g}$ ); while lowest mean fungal count was recorded in sample 4 from Ariaria market $\left(2.2 \times 10^{3} \pm 0.02 \mathrm{SFU} / \mathrm{g}\right)$. Samples from Cemetery market recorded the highest mean fungal counts while that from Ariaria market recorded the lowest mean fungal counts. Counts obtained within samples of same market when compared were statistically significant $(\mathrm{p}<0.05)$. 
Table 1. Mean fungal count (MFC) of smoked catfish samples sold in Aba metropolis

\begin{tabular}{llllll}
\hline SAMPLE & AFM $(\mathbf{S F U} / \mathbf{g})$ & ARM $($ SFU/g) & UMM $(\mathbf{S F U} / \mathbf{g})$ & $\mathbf{C E M}(\mathbf{S F U} / \mathbf{g})$ & AHM(SFU/g) \\
\hline Sample 1 & $4.2 \times 10^{3} \pm 0.02^{\mathrm{b}}$ & $2.1 \times 10^{4} \pm 0.10^{\mathrm{ab}}$ & $3.5 \times 10^{3} \pm 0.05^{\mathrm{d}}$ & $3.9 \times 10^{3} \pm 0.05^{\mathrm{d}}$ & $2.7 \times 10^{4} \pm 0.08^{\mathrm{a}}$ \\
Sample 2 & $2.7 \times 10^{4} \pm 0.02^{\mathrm{ab}}$ & $1.4 \times 10^{4} \pm 0.09^{\mathrm{bc}}$ & $3.0 \times 10^{4} \pm 0.03^{\mathrm{a}}$ & $3.5 \times 10^{3} \pm 0.08^{\mathrm{e}}$ & $1.3 \times 10^{4} \pm 0.02^{\mathrm{bc}}$ \\
Sample 3 & $3.2 \times 10^{3} \pm 0.03^{\mathrm{cd}}$ & $2.4 \times 10^{4} \pm 0.04^{\mathrm{a}}$ & $2.7 \times 10^{4} \pm 0.01^{\mathrm{ab}}$ & $4.5 \times 10^{4} \pm 0.14^{\mathrm{a}}$ & $2.3 \times 10^{4} \pm 0.08^{\mathrm{ab}}$ \\
Sample 4 & $3.4 \times 10^{3} \pm 0.02^{\mathrm{c}}$ & $2.2 \times 10^{3} \pm 0.02^{\mathrm{de}}$ & $2.1 \times 10^{4} \pm 0.04^{\mathrm{bc}}$ & $5.5 \times 10^{3} \pm 0.03^{\mathrm{c}}$ & $3.3 \times 10^{3} \pm 0.03^{\mathrm{d}}$ \\
Sample 5 & $3.4 \times 10^{4} \pm 0.12^{\mathrm{a}}$ & $2.7 \times 10^{3} \pm 0.08^{\mathrm{d}}$ & $2.0 \times 10^{4} \pm 0.09^{\mathrm{bc}}$ & $3.5 \times 10^{4} \pm 0.05^{\mathrm{ab}}$ & $2.7 \times 10^{4} \pm 0.04^{\mathrm{a}}$ \\
\hline
\end{tabular}

Values are given as mean \pm SD. Within column, values followed by the same alphabets are not significantly different but those followed by different alphabets are significantly different. Legend: AFM - Afule market, ARM - Ariaria market, UMM - Umugasi market, CEM - Cemetery market and AHM Ahiaohuru market, SPU - Spore Forming Unit.

The macroscopic and microscopic identification of fungi associated with spoilage of smoked catfish indicated a total of four (4) fungal isolates were identified. These include Aspergillus niger, Mucor species, Candida species and Rhodotorula species. The percentage prevalence of isolated fungi associated with smoked catfish samples is shown in Figures 1 to 5. In Figures 1, 2 and 4 of Afule, Ariaria and Cemetry markets, the most prevalent fungi (\%) was Aspergillus niger (60; $46.67 ; 80)$, while the least prevalent (\%) was Rhodotorula species $(20 ; 13.33 ; 6.67)$ respectively. In Figure 3 , the most prevalent fungi (\%) in smoked catfish sold at Umugasi market was Mucor species (73.33), while the least prevalent (\%)was Rhodotorula species (6.67). In Figure 5, the most prevalent fungal species in smoked catfish sold at Cemetery market were Aspergillus niger and Candida species (66.67) while the least prevalent was Rhodotorula species (13.33).

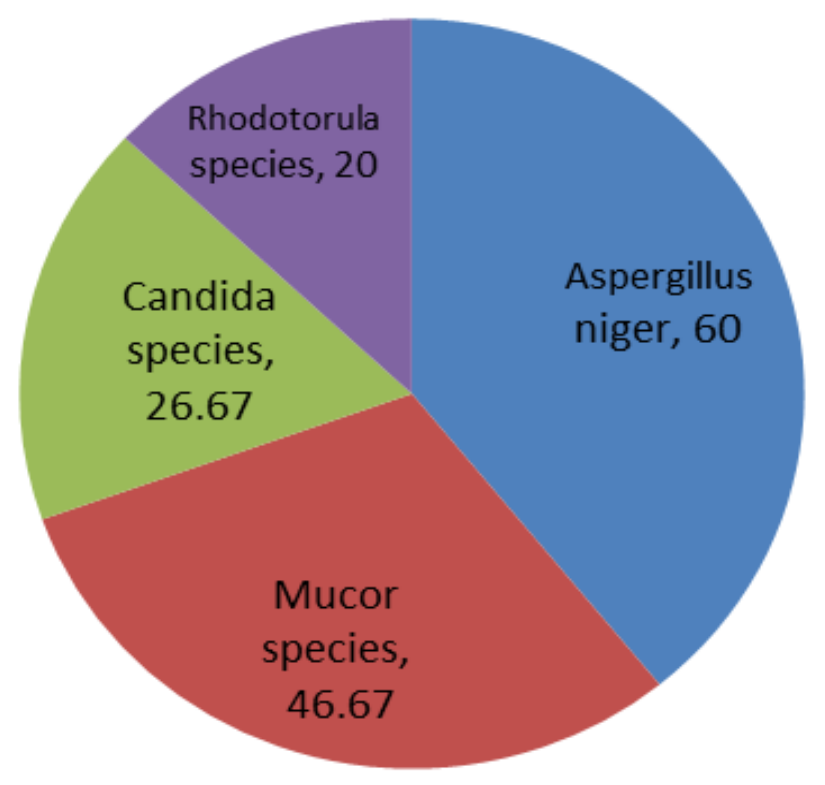

Figure 1. Percentage prevalence of isolated fungi from Afule market 


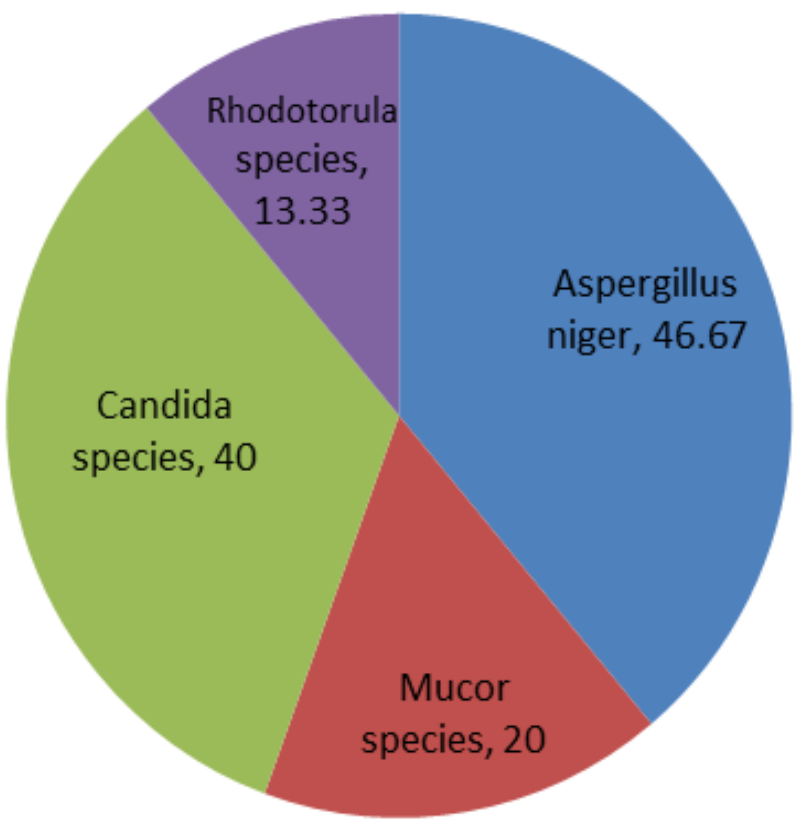

Figure 2. Percentage prevalence of isolated fungi from Ariaria market

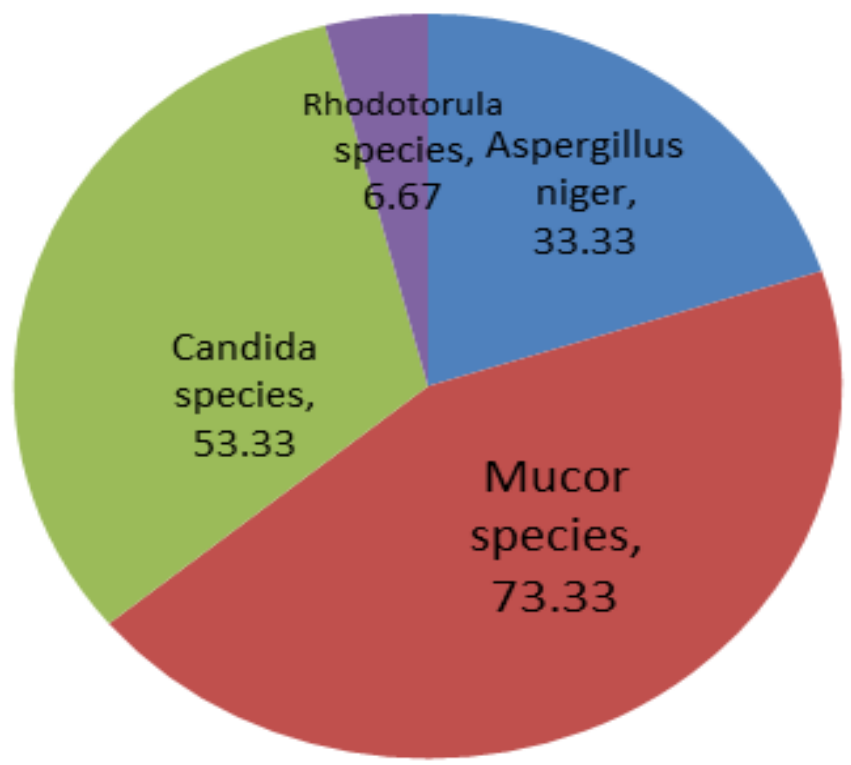

Figure 3. Percentage prevalence of isolated fungi from Umugasi market 


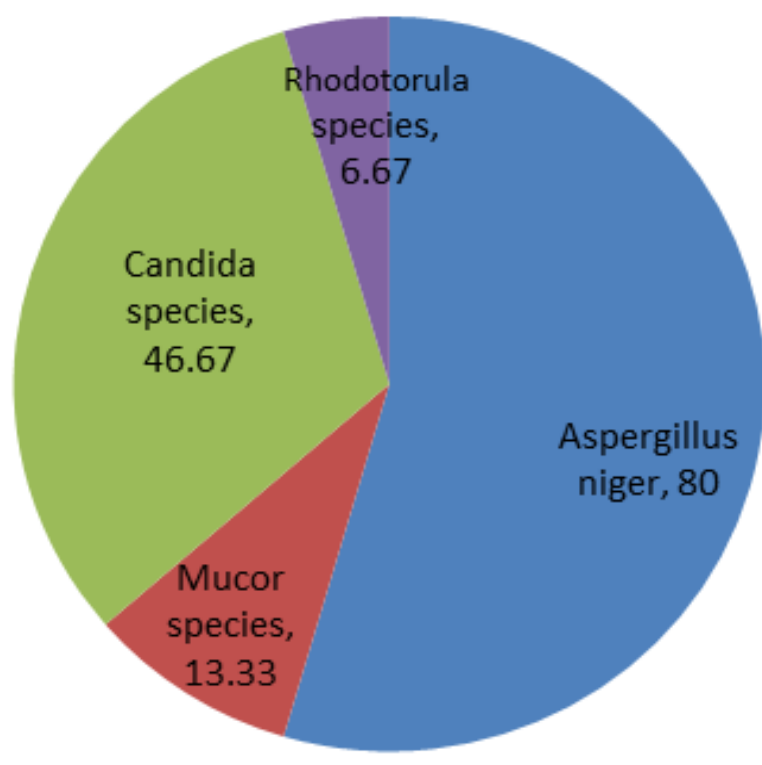

Figure 4. Percentage prevalence of isolated fungi from Cemetery market

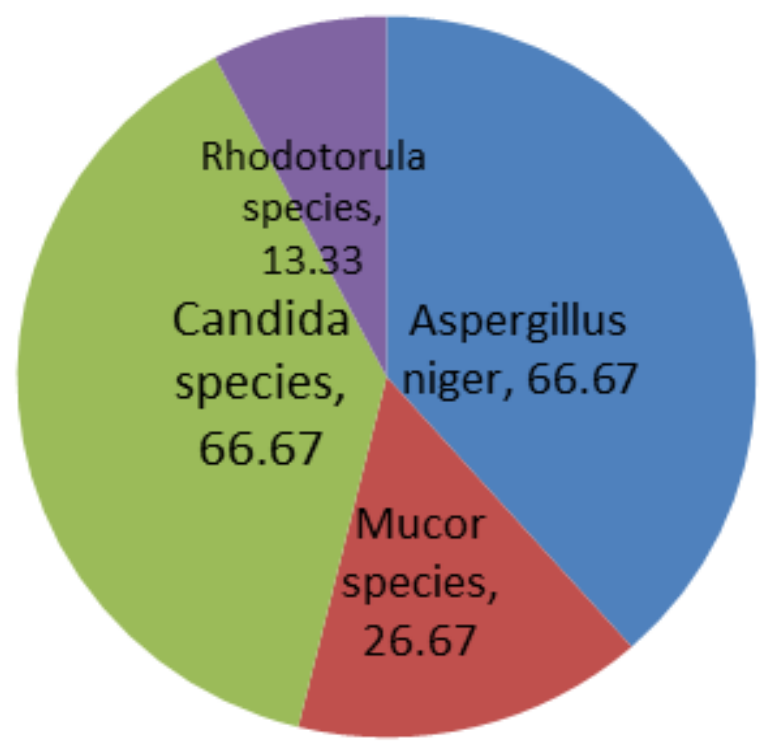

Figure 5. Percentage prevalence of isolated fungi from Ahiaohuru market

\section{Discussion}

The mean fungal counts of smoked catfish sold in Aba revealed that samples from Cemetery market recorded the highest mean fungal counts while that from Ariaria market had the lowest mean counts. A total of four fungal isolates were identified which include Aspergillus niger, Mucor species, Candida species, and Rhodotorula species. Aspergillus niger, Mucor and Candida species were the predominant mycoflora in market samples. Most of the organisms found in these smoked fish are those commonly found in soil and water environments.

Aspergillus niger is most commonly found in mesophilic environments such as decaying vegetation or soil and plants [15]. Generally, fungi grow and survive at optimal conditions especially in humid environments. Hence, they require a water activity value between $0.80-0.93$ [16]. A close observation at Table 1 for fungal counts and figures 1-5 for fungal prevalence showed that Cemetery market had the highest fungal count and prevalence for 
Aspergillus niger when compared with other markets. This is followed by Afule and Ariaria markets respectively. Conversely, Umungasi market had Mucor species as the most prevalent, while Ahiaohuru market had both Aspergillus and Candida species as the most prevalent. The obtained result was due to the ability of the fungi to grow in wide temperature 6-47 ${ }^{\circ} \mathrm{C}$ and $\mathrm{pH}$ ranges 1.4-9.8 [17]. [18] reported Aspergillus niger as one of the commonest microorganisms associated with smoked fish when he developed biochemical applications in fisheries processing.

Mucor thrives in soil, plants, manure, decaying fruits, vegetables and as a common contaminant of stored and processed foods in the kitchen. Mucor species can grow at high temperatures (thermo-tolerant), may cause infections in man. However, most Mucor species are unable to infect humans and warm blooded animals due to their inability to grow in warm environments close to $37^{\circ} \mathrm{C}$ [14]. Figure 3 showed that Mucor species had the highest percentage prevalence in Umungasi market. This could be attributed to the storage conditions of the fish by fish handlers and cold or moist environment due to frequent rainfall in Aba. [3] reported that fungal species encountered in the fresh fish include: Penicillium species, Aspergillus flavus, Aspergillus niger, Fusarium species, Mucor species, and Rhizopus stolonifer could either come from the surrounding environment, fishing equipment, habitat or handlers.

Rhodotorula species are ubiquitous saprophytic yeasts that can be recovered from many environmental sources including air, soil, seawater, plants, dairy products, and the household environment e.g., shower curtains, bathtub grout [19]. The presence of Rhodotorula species could be attributed to the surrounding environment as was reported by [20]. Although, Rhodotorula species recorded the lowest prevalence in all the markets, its presence in smoked catfish could be due to its ubiquitous nature.

Candida is a yeast and the most common cause of opportunistic mycoses worldwide [21]. It is also a frequent colonizer of human skin and mucous membranes. Candida is a member of normal flora of skin, mouth, vagina, and stool. Most often, it is found in the environment, particularly on leaves, flowers, water, and soil [21]. Candida species was the second predominant fungal isolate after Aspergillus niger in all the markets as shown in Figures 1-5. The presence of Candida species in smoked catfish may be due to contamination from fish handlers or indiscriminate storage of fish on swampy or water-logged soil.

The growth of fungus on dried fish products could cause spoilage, discolouration, rotting, alters the flavour and textural quality of dry fish which leads to loss of nutrients quality and huge economic loss [10]. The processed fish are easily contaminated with microorganisms, through improper handling and processing; and unhygienic post-processing handling [8; 22]. Smoked fish become contaminated and spoiled by different microorganisms from their processing through storage to marketing [8]. Results obtained from this study revealed that Aspergillus niger, Mucor species, Candida species and Rhodotorula species were associated with smoked catfish, and this assertion is in agreement with the findings reported by $3 ; 11 ; 18 ; 20 ; 23 ; 24$; and 25. Similar microorganisms were also reported by [26] in smoked fish (Clarias species.) sold in Benin metropolis.

\section{Conclusion}

Findings from this study showed that the smoked catfish sold in Aba metropolis are improperly smoked leading to the deterioration of the fish. The high occurrence of the fungal isolates recorded in smoked catfish sold in Aba metropolis is an indication of improper adherence to hygienic conditions before and after smoking. Therefore, there is need to educate fish handlers, vendors and retailers about the adoption of good hygienic practices and standards. Fish should be smoked properly to reduce both the risk of contamination and water values as it controls growth of fungi on substrates. It is also recommended that smoked catfish and fish products bought from markets should be cooked properly before eating.

\section{Compliance with ethical standards}

\section{Acknowledgments}

The authors are grateful to everyone who contributed in achieving this feat.

\section{Disclosure of conflict of interest}

No conflict of interest of any sort. 


\section{References}

[1] Abolagba OJ and Melle 00. (2008). Chemical composition and keeping qualities of a scaly fish tilapia (oreochromisniloticus) smoked with two energy sources. African Journal of Genetic Agriculture, 4, 113-117.

[2] Eyo AA. (2001).Chemical composition and amino acid content of the commonly available feedstuff in Nigeria. in fish nutrition and fish feed technology. Proceedings of first national symposium on fish nutrition and fish feed technology held at niomar Lagos, 15-26.

[3] Awe S and Adejo SO. (2018). Microorganisms associated with selected fresh fishes from river niger, lokoja and their antibiotic susceptibility.International Journal of Agriculture Innovations and Research Volume, 6(4), 136141.

[4] Tobor JG. (1984). A review of the fishing industry in Nigeria and status of fish preservation methods and future growth prerequisites to cope with anticipated increase in production niomr tech pap.Nigerian Food Journal, 2, 105-108.

[5] Eyo, A.A. (1992). Traditional and improved fish handling, preservation and processing techniques. naerls/nifer national workshop on fish processing, storage, marketing and utilization, 15.

[6] Akande GR and Tobor JG. (1992). Improved utilization and increased availability of fishing products as an effective control of aggravated animal protein deficiency induced malnutrition in Nigeria Proceedings of the 10 annual conference of the fisheries society of Nigeria, 18-31.

[7] Simko P. (1991). Changes of benzo(a)pyrene contents in smoked fish during storage. Food Chemistry, 40, 293300.

[8] Dutta M, Majumdar PR, Islam RU and Saha D. (2018). Bacterial and fungal population assessment in smoked fish during storage period. Journal of Food Microbiology Safety and Hygiene, 3, 127.

[9] Akise OG, Abolagba OJ and Eyong MM. (2013). Mycoflora of three fish species smoke-dried using rubber wood (hevea brassillensis) in Nigeria. Greener Journal of Agricultural Sciences, 3(5), 396-402.

[10] Sivaraman GK, Visnuvinayagam S and Ashish KJ. (2016).Microbiological spoilage of dried fishes. Central Institute of Fisheries Technology, 1 (1), 1-5.

[11] Jimoh WA, Ayeloja AA, Oladele-Bukola MO, Adebayo MD, Azeez AF and Salami SR. (2014). Isolation of fungi infesting smoked african catfish from markets in Ibadan, Nigeria. Nigerian Journal of Fisheries and Aquaculture, $2(2), 13-17$.

[12] Gram L, Oundo JO and Bon J. (2000). Shelf-life of fish depends on storage temperature and initial bacterial load. Tropical Science, 25, 28 - 30.

[13] Cappucino GJR and Sherman B. (2010). Microbiology: A Laboratory Manual, Nineth Edition.The Benjamin Publishing Coy. California.

[14] Kidd S, Halliday C, Alexiou H and Ellis D. (2016).Description of Medical Fungi. $3^{\text {rd }}$ Edition. Newstlye Printing. Adelaide, South Australia 5031, Australia, 23-170.

[15] Schuster E, Dunn-Coleman N, Frisvad J and van Dijck P. (2002). On the safety of Aspergillus niger-A review. Applied Microbiology of Biotechnology, 59, 426-435.

[16] Jay MJ, Loessner MJ and Golden DA. (2005).Modern Food Microbiology, Seventh Edition. Springer Publishers, USA, 45-46.

[17] Ajay KG, Sushil S, Shubhi A and Rekha B. (2011).Diversity, Pathogenicity and Toxicology of A. niger: An Important Spoilage Fungi. Research Journal of Microbiology, 6(3), 270-280.

[18] Martins AM. (1994). Fisheries processing: Biochemical applications. Published by Chapman and Hall, London, 188.

[19] Wirth F and Goldani LZ. (2012). Epidemiology of Rhodotorula: an emerging pathogen. Interdisciplinary Perspective on Infectious Diseases.

[20] Ike CC, Emeka-Ike PC, Nwokorie CC and Anochie CC. (2015). Microbiological Quality of Locally Prepared Snacks sold in Aba Metropolis, Abia State, Nigeria. International Journal of Scientific Engineering and Applied Science (IJSEAS), 1(7), 46-59. 
[21] Mold and Bacteria Consulting Laboratories, (MBL). (2019). Mucor.

[22] Basti AA, Misaghi A, Salehi TZ and Kamkar A. (2006). Bacterial pathogens in fresh, smoked, and salted Iranian fish. Food Control, 17, 183-188.

[23] Fafioye 00, Fagbohun TR and Olubanjo 00. (2008).Fungal infestation and nutrient quality of traditionally smokedried freshwater fish. Turkish Journal of Fisheries and Aquatic Sciences, 8, 7-13.

[24] Adebayo-Tayo BC, Onilude AA and Ukpe PG. (2008). Mycofloral of smoke-dried fishes sold in Uyo, Eastern Nigeria. World Journal of Agricultural Sciences, 4(3), 346-350.

[25] Wogu MD and Maduakor CC. (2010).Evaluation of microbial spoilage of some aquacultured fresh fish in Benin City Nigeria. Ethiopian Journal of Environmental Studies and Management, 3, 3-12.

[26] Abolagba OJ and Igbinevbo EE. (2010). Microbial load of smoked fish (clarias sp) marketed in Benin metropolis, Nigeria. Research Journal of Fisheries and Hydrobiology, 5(2), 99-104.

\section{How to cite this article}

Ike CC, David AC, Ogwuegbu HO and Akwari DK. (2020). Fungal profile associated with spoilage of smoked catfish sold in Aba, Abia State, Nigeria. GSC Biological and Pharmaceutical Sciences, 10(3), 110-117. 